\title{
Benign pheochromocytoma associated with colorectal cancer: Case report
}

\author{
Kolorektal kansere eşlik eden benign feokromositoma: Olgu sunumu
}

Turgut Kaçan*, Saadettin Kılıçkap, Nalan Akgün Babacan, Mehmet Metin Şeker, Birsen Yücel, İlknur Koç Olçaş, Gülşah Gültekin, Mehmet Fuat Eren, Ayfer Ay Eren

Departments of Medical Oncology (T. Kaçan, MD, Assist. Prof. S. Kılıçkap, MD, Assist. Prof. N. A. Babacan, MD, Assist. Prof. M. M. Şeker, MD), Departments of Radiation Oncology (Assist. Prof. B. Yücel, MD, Assist. Prof. M. F. Eren, MD, Assist. Prof. A. A. Eren, MD), Department of Internal medicine (G. Gültekin, MD, İ.K.Olçaş, MD), Cumhuriyet University School of Medicine, TR-58140 Sivas

\begin{abstract}
Among all cancers, colorectal cancer is the second leading cause of cancer related death. Liver and lung are known as the main metastatic sites of colorectal cancer, on the other hand the metastasis of adrenal is clinically rare. Formerly, metastases were detected at autopsy, but due to improved imaging and diagnostic techniques, many of these lesions now can be detected on routine followup imaging. Patients with adrenal metastasis are considered having systemic spread and therefore unsuitable for surgical resection. That's why, isolated adrenal metastasis presents a therapeutic dilemma in colorectal cancer patients. In this case, we report an adrenal mass in a patient with colorectal cancer to whom rectosigmoidectomy, colectomy and adrenal metastasectomy were performed. The adrenal mass was benign. For solitary and resectable lesions adrenalectomy can be performed and prolonged survival can be achieved in selected patients. Also, this enables to achieve right histopathological diagnosis.
\end{abstract}

Keywords: Colorectal cancer, adrenal mass, adrenalectomy

\section{Özet}

Kolorektal kanser tüm kanserler arasında ölüme neden olan ikinci sıklıktaki kanserdir. Karaciğer ve akciğer kolorektal kanserlerin ana metastaz yerleri iken adrenal metastaz klinik olarak nadirdir. Eskiden metastazlar otopsilerde saptanırken, görüntüleme ve tanısal tekniklerin gelişmesi sayesinde rutin takiplerde fark edilebilir. Adrenal metastazı olan hastalar diffüz sistemik yayılım kabul edilir ve cerrahi rezeksiyona uygun değillerdir. Bu nedenle kolorektal kanserli hastalarda izole adrenal metastaz tedavide ikilem yaratmaktadır. Bu olguda hemikolektomi ve adrenal metastazektomi uygulanan kolorektal kanserli hastada adrenal kitleyi rapor etmekteyiz. Adrenal kitle iyi huylu idi. Rezeksiyona uygun klinik soliter lezyonlar seçili hastalarda yapılabilir ve uzun süreli sağkalım sağlar. Aynı zamanda doğru tanının konmasını sağlar.

Anahtar sözcükler: Kolorektal kanser, adrenal kitle, adrenalektomi

Geliş tarihi/Received: December 23, 2012; Kabul tarihi/Accepted: May 20, 2013

*Corresponding author:

Dr. Turgut Kaçan, Onkoloji Anabilim Dalı, Cumhuriyet Üniversitesi Tıp Fakültesi, TR-58140 Sivas. E-mail: kacanturgut@gmail.com

\section{Introduction}

Among all cancers, colorectal cancer is the second leading cause of cancer related death. Although the liver and the lung are the main metastatic sites of colorectal cancer, the adrenal metastasis is clinically rare. Adrenal metastases most commonly occur in patients with lung and breast cancer [1,2]. Generally, metastasis to the adrenal glands are regarded as an indicator of wide spread disease, but in rare cases, isolated adrenal metastasis can also exist [3-5]. However, benign tumours of the adrenal gland such as 
pheochromocytoma may cause misdiagnosis in cancer patients so that patients may be misinterpreted as evidence of having metastatic disease. Thus, this is a diagnostic challenge for physician and source of anxiety for the patients [6-8].

\section{Case report}

A 55-year-old female was admitted to the hospital with abdominal distension and tenesmus. There was no family history for malignancy.

In physical examination, there was an incision scar. The other examinations were normal. In laboratory findings (Table 1), the tumour was non-functional and carcinoembryonic antigen (CEA) was high. Rectosigmoidoscopy was performed and an ulcerovegetant tumoural mass was found at $15 \mathrm{~cm}$ from anal verge. Biopsy was performed. Histopathology of the biopsy specimen showed adenocarcinoma of rectum. For staging, MRI of the abdomen (Figure 1) and PET-CT (Figure 2) were performed. Abdominal MRI detected a tumour of $35 \times 30 \mathrm{~mm}$ in the left adrenal gland. PET-CT showed a mass in rectosigmoid junction with a high fluorodeoxy glucose uptake (SUV max: 23.7) and a mass in left adrenal gland (SUV max: 12.0). She applied to Cumhuriyet University in Sivas.

Tablo 1. Laboratory findings.

\begin{tabular}{ll}
\hline Leukocyte $(4-11 \times 103 / \mu \mathrm{L})$ & 5,630 \\
Neutrophil $(1.8-7.0 \times 103 / \mu \mathrm{L})$ & 2,460 \\
Hemoglobin $(14-18 \mathrm{~g} / \mathrm{dL})$ & 12.9 \\
Platelet $(150-00 \times 103 / \mu \mathrm{L})$ & 325 \\
Glucose $(\mathrm{mg} / \mathrm{dL})$ & 104 \\
Creatinine $(\mathrm{mg} / \mathrm{dL})$ & 0.69 \\
Uric acid $(\mathrm{mg} / \mathrm{dL})$ & 3.9 \\
Total protein $(\mathrm{mg} / \mathrm{dL})$ & 7.0 \\
Albumin $(\mathrm{mg} / \mathrm{dL})$ & 3.4 \\
CEA ng/mL & 5.93 \\
Calcium $\mathrm{U} / \mathrm{mL}$ & 17.6 \\
TSH mIU/mL & 1.1 \\
Cortisol $\mu \mathrm{g} / \mathrm{dL}$ & 21.84 \\
DHEAS $\mu \mathrm{g} / \mathrm{dL}$ & 142.4 \\
$11 \mathrm{DOC} \mathrm{ng} / \mathrm{mL}$ & 0.14 \\
Aldosteron ng/dL & 488 \\
PRA ng/mL/h & 1.66 \\
\hline
\end{tabular}

CEA: Carcinoembryonic antigen, DHEAS: Dehydroepiandrosterone sulfate,

TSH: Thyroid Stimulating Hormone, 11 DOC: Deoxycortisol, PRA: Plasma Renin Activity

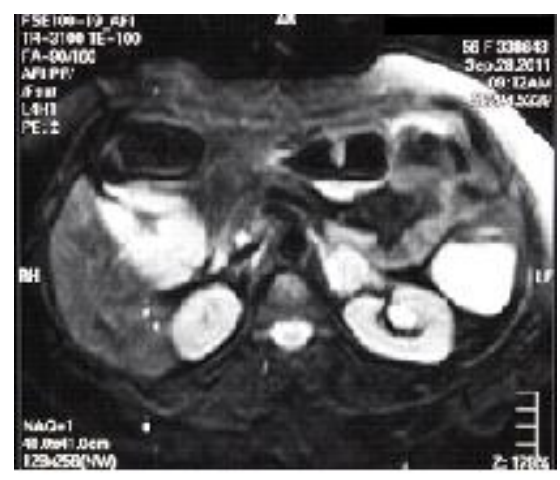

Figure 1. Magnetic resonance imaging showing a tumour of $35 \times 30 \mathrm{~mm}$ in the left adrenal gland. 
Rectosigmoidectomy, colectomy and adrenal metastasectomy were performed. Her postoperative course was evenful. The histopathologic results of rectum specimen and adrenal mass revealed adenocarcinoma and benign pheochromocytoma respectively. According to the TNM classification the patient had stage 3 tumour. Therefore we applied 8 cycles of adjuvant chemotherapy with FOLFOX-6 (oxaliplatin, $85 \mathrm{mg} / \mathrm{m}^{2} ; \mathrm{d} 1$, leucoverin $200 \mathrm{mg} / \mathrm{m}^{2}$; d 15 fluorouracil bolus $400 \mathrm{mg} / \mathrm{m}^{2}$; $\mathrm{d} 1$ and $2400 \mathrm{mg} / \mathrm{m}^{2} 46$ hoursinfusion). The patient is still disease-free.

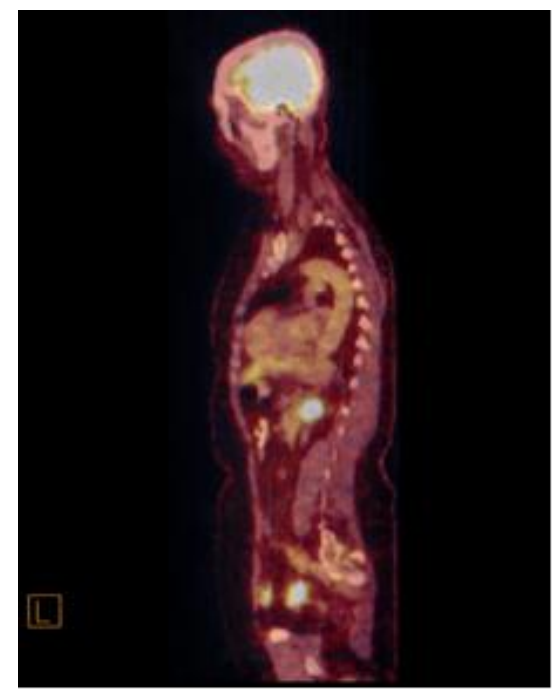

Figure 2. PET-CT showing FDG uptake in a rectal tumour (SUV max: 23.7) and adrenal metastasis (SUV max: 12.0).

\section{Discussion}

Although the liver and the lung are the main metastatic sites of $\mathrm{CRC}$, the adrenal metastasis is clinically rare. But in autopsy series, the metastasis ranges are from $1.9 \%$ to $17.4[1,9]$. The rate of detecting clinically silent adrenal masses has increased due to the widespread use of abdominal imaging modalities, including USG, PET-CT, MRI [10-12].

When an adrenal mass is detected in a cancer patient, it is important to determine whether it is a metastasis or not. In these patients, adrenal mass may be a solitary adrenal adenoma, adrenocortical carcinoma or metastasis. An adrenal metastasis in cancer patients is usually found as part of widespread metastasis, but in some cases it occurs as a solitary adrenal metastasis. Currently, isolated adrenal metastasis can be confused with benign adrenal tumours such as adenoma and pheochromocytoma. To identify the adrenal mass is either malign or benign biopsy should be performed. In autopsy studies, the prevalence of incidentaloma is 1-9\% [13] and the rate of metastasis ranges from 1.9$17.4 \%[1,9]$. It is generally accepted that a solitary adrenal metastasis should be resected immediately to achieve good prognosis in some cancer types [14-15]. According to the histopathological diagnosis, chemoregimen might be changed [14].

Laparoscopic adrenalectomy has replaced open adrenalectomy as a procedure of choice for adrenal tumours. However, the efficacy of laparoscopic resection is controversial for large, potentially malignant adrenal tumours. [16]. Therefore it is essential to differentiate benign and non-functional lesions. Isolated adrenal mass should be determined as either benign or malign.

In our case, imaging modalities showed an adrenal metastasis. Therefore the stage of tumour was 4. Rectosigmoidectomy, colectomy and adrenal metastasectomy were performed. The histopathology results showed adenocarcinoma in rectum and benign pheochromocytoma for the adrenal mass. 
As a conclusion, isolated adrenal metastasis confuses with benign adrenal tumours such as adenoma and pheochromocytoma. Adrenalectomy for solitary, resectable lesions can be performed and prolonged survival can be achieved in selected patients.

\section{References}

1. Kim SH, Brennan MF, Russo P, Burt ME, Coit DG.The role of surgery in the treatment of clinically isolated adrenal metastasis. Cancer 1998; 82: 389-94.

2. Murakami S, Terakado M, Hashimoto T, Tsuji Y, Okubo K, Hirayama R. Adrenal metastasis from rectal cancer: Report of a case. Surg Today 2003; 33: 126-30.

3. Katayama A, Mafune K, Makuuchi M. Adrenalectomy for solitary adrenal metastasis from colorectal carcinoma. Jpn J Clin Oncol 2000; 30: 414-6.

4. Adler JT, Mack E, Chen H. Equal oncologic results for laparoscopic and open resection of adrenal metastases. J Surg Res 2007; 140: 159-64.

5. Nagakura S, Shirai Y, Nomura T, Hatakeyama K. Long-term survival after resection of colonic adenocarcinoma with synchronous metastases to the liver, adrenal gland, and aortic-caval lymph nodes: Report of a case. Dis Colon Rectum 2002; 45: 1679-80.

6. Kanjo T, Albertini M, Weber S. Long-term disease-free survival after adrenalectomy for isolated colorectal metastases. Asian J Surg 2006; 29: 291-3.

7. Mitchell IC, Nwariaku FE. Adrenal masses in the cancer patient: Surveillance or excision. Oncologist 2007; 12: 168-74.

8. Sancho JJ, Triponez F, Montet X, Sitges-Serra A. Surgical management of adrenal metastases. Langenbecks Arch Surg 2012; 397: 179-94.

9. Kosmidis C, Efthimiadis C, Anthimidis G, Levva S, Ioannidou G, Zaramboukas T, Emmanouilides C, Baka S, Kosmidou M, Basdanis G, Fachantidis E. Adrenalectomy for solitary adrenal metastasis from colorectal cancer: A case report. Cases J 2008; 1: 49.

10. Bovio S, Cataldi A, Reimondo G, Sperone P, Novello S, Berruti A, Borasio P, Fava C, Dogliotti L, Scagliotti GV, Angeli A, Terzolo M. Prevalence of adrenal incidentaloma in a contemporary computerized tomography series. J Endocrinol Invest 2006; 29: 298-302.

11. Hood MN, Ho VB, Smirniotopoulos JG, Szumowski J. Chemical shift: The artifact and clinical tool revisited. Radiographics 1999; 19: 357-71.

12. Blake MA, Prakash P, Cronin CG. PET/CT for adrenal assessment. AJR Am J Roentgenol. 2010; 195: 91-5.

13. Terzolo M, Stigliano A, Chiodini I, Loli P, Furlani L, Arnaldi G, Reimondo G, Pia A, Toscano V, Zini M, Borretta G, Papini E, Garofalo P, Allolio B, Dupas B, Mantero F, Tabarin A; Italian Association of Clinical Endocrinologists. AME position statement on adrenal incidentaloma. Eur J Endocrinol 2011; 164: 851.

14. Gundgaard MG, Soerensen JB, Ehrnrooth E. Third-line therapy for metastatic colorectal cancer. Cancer Chemother Pharmacol 2008; 61: 1-13.

15. Heniford BT, Arca MJ, Walsh RM, Gill IS. Laparoscopic adrenalectomy for cancer. Semin Surg Oncol 1999; 16: 293-306.

16. Zografos GN, Markou A, Ageli C, Kopanakis N, Koutmos S, Kaltsas G, Piaditis G, Papastratis G. Laparoscopic surgery for adrenal tumors. A retrospective analysis. Hormones (Athens) 2006; 5: 52-6. 